\title{
ACRL STANDARDS AND GUIDELINES \\ Guidelines for media resources in academic libraries
}

\author{
Prepared by the ACRL Media Resources Committee
}

$\mathrm{E}$ d note: These guidelines were approved by the ACRL Board at the 1999 Midwinter Meeting and by the ALA Standards Committee in March 1999.

These guidelines were prepared by members of the Media Resources Committee (formerly the Audiovisual Committee) of the Association of College and Research Libraries. They have been extensively revised and supersede the guidelines developed and published by the Audiovisual Committee in 1987.

\section{Foreword}

Technology used in teaching, learning, and research has created new challenges and opportunities for managers of college and university library media resource collections and services. Faculty and students need traditional media formats-audiocassettes, audio compact discs, videocassettes, laserdiscs, and so on-but librarians must also consider computer technology and emerging digital formats.

Within the library, the boundary between media collections and services and computer software collections and services has blurred. Academic librarians are also working closely with other agencies on campus to support faculty and student information needs. In some institutions, librarians have become true partners in the delivery of instruction, working with faculty, technologists, and instructional developers to create "new learning communities."

Studies show that most academic libraries collect media materials, primarily audio and video formats. Indeed, media collections are as diverse and vital as any print collection in an academic library. An academic library media operation may encompass a variety of activities, such as scheduling and managing the delivery of audiovisual equipment to classrooms, operating distance education television studios, offering instructional development and the production of audiovisual materials, and supporting multimedia production. However, this document will address only the core issues related to collecting and maintaining media resources and their attendant services.

Earlier versions of the guidelines (1968, 1987) could not have anticipated the rapid growth and the prevalence of digital media today. Digital media include digital formats, such as audio compact disc and digital versatile disc (DVD), and interactive multimedia, such as CD-ROM and DVD-ROM.

Media resources can now be delivered via the Web, digital satellite systems, and a host of rapidly developing technologies. In the past, media librarians were able to focus on a narrow array of formats. Today we must widen the scope of our collection development activities, considering digital formats and multimedia along with traditional ana$\log$ formats.

Media librarians should be advocates for viable new media technologies, expanding their knowledge base to include digital delivery systems. While supporting traditional formats, media librarians must assess rapidly evolving new formats and be ready to adopt them when they stabilize and when it has been determined that they meet content and programmatic needs within the institution. We must move more quickly than in the past to incorporate them into our collections. Libraries must plan for format adoption.

Networked information is the future and many new digital library initiatives are offering media resources. At the same time, we must be sensitive to the needs of our users 
and to the pace of institutional change. This can only be done within a context of collaborative relationship involving media librarians, library administrators, computing service personnel, and the users of our media resource collections.

The goal of the 1999 "Guidelines for Media Resources in Academic Libraries" is to assist librarians and library administrators who are developing media collections and services. Although the guidelines are not a practitioner's manual, we hope that they will be helpful to librarians at all levels of the organization who want to improve media resource collections and services.

\section{Assumptions}

For the first time, we prefaced the guidelines with a set of assumptions. The allthors of the 1967 guidelines wrote, "The philosophy of library services that has evolved through the years can readily be applied to audio-visual materials. The librarian's ability to select, organize, and service materials applies to all types of learning resources" (p. iv).

We agree with these statements. Rather than dwelling on the similarities between print and media collections, we covered those points in the assumptions. In the guidelines themselves, we focused on the differences. Furthermore, research and experience over the past 30 years have taught us that some practices are more effective than others in building useful collections and meeting our users' needs for mediarelated services. The guidelines reflect this knowledge. The recommended guidelines represent best practices for an academic library media program. Collectively, they describe a model media resources program. In this document, "media resources program" refers to all aspects of media resource collections and services in the library.

Assumption 1: All academic libraries will collect media resources. Some academic libraries exclucle some or all media formats from their collections. However, ACRL standards for academic libraries specify that the library shall select and acquire materials in all formats. If only one media collection exists on a college or university campus, that collection and its attendant services should be part of the library. The library staff is uniquely qualified to provide the best access to that $\mathrm{col}-$ lection, both physical and bibliographic. The library is also the most qualified to build planned collections, responsive to both immediate and anticipated programmatic needs. If another administrative unit on campus also collects media, it is assumed that the library will coordinate its efforts with that unit.

Assumption 2: All media resources will be cataloged in accordance with current national standards and practices, including full subject access and classification. Some academic libraries exclude media resources from the online catalog or provide only minimal-level cataloging. Many academic libraries do not classify media resources. These practices result in inadequate access to media collections. Some media materials require more timely cataloging and, thus, should be eligible for rush cataloging and processing.

Assumption 3: All academic libraries will provide adequate funding for media services and collections; "adequate funding" is determined by the library's goals and objectives for media services and collections. ACRL standards provide evaluative measures for the adequacy of the budget. These measures should be applied to funding for media collections and services.

Assumption 4: The principles of collection management that apply to print and other library collections also apply to media resources. Media collections require policies and procedures for purchase, leasing, renting, deselection, resource sharing, and licensing.

Assumption 5: The principles of collection preservation that apply to print and other library collections also apply to media resources. The library program for conservation and preservation should encompass both archival and access media collections.

Assumption 6: The principles of library service that apply to other library services also apply to media services. Reference and instruction programs should include locating and using appropriate media resources for instruction and research. 


\section{Background on AudiovisualMedia Resources Guidelines}

The 1999 "Guidelines for Media Resources in Academic Libraries" are only the third set of guidelines for audiovisual materials or media resources adopted by the Association of College and Research Libraries (ACRL). The Audio-Visual Committee of ACRL published the first Guidelines for Audio-Visual Services in Academic Libraries in 1968 (reprinted in 1969). You will not find it listed in Library Literature because the guidelines were pulylished as a 24-page monograph. The purpose of the guidelines was "to supply basis assistance to those academic libraries that will assume all or a major portion of an atıdiovisual progran" (p. iv). Since few academic libraries had audiovisual collections at that time, the authors emphasized the demonstrated effectiveness of using audiovisual materials in instruction and provided practical suggestions for developing and maintaining these collections. Early audiovisual collections in academic libraries typically included $16 \mathrm{~mm}$ films, slides, reel-to-reel audio recordings, and phonograph records.

Nearly 20 years later, the authors of the 1987 "Guidelines for Audiovisual Services in Academic Libraries" noted the extraordinary technological changes that had occurred since the adoption of the 1968 guidelines. By 1987 it was no longer necessary to convince librarians that audiovisual materials are valuable resources for instruction. The forward to the 1987 guidelines noted the potential of audiovisual materials to support research, as well as instruction. The authors of this revision had seen the advent of new formats, such as VHS videocassettes, audiocassettes, laserdiscs, and audio compact discs, which had brought audiovisual materials into a majority of academic libraries. The emerging issues in 1987 were related to adopting new formats and providing equipment and technical support for them. Although CD-ROMs were becoming popular in academic libraries, they were text-only at this time and not a concern to media librarians; multimedia CD-ROMs made their debut around 1990.

The years between 1987 and 1999 marked a revolution in media resource collections and services. During this time media librarians grappled with a major technological devel- opment, the introduction of multimedia CDROMs. Until the early 1990 s, media resource collections, both analog (magnetic tape and phonograph records) and digital (optical discs), were played on a single-use machine. Multimedia CD-ROMs introduced interactive media to the mix. Users require an expensive computer, equipped with a CI)-ROM drive, a sound card, and a video card to use most software. Just as media libratians were beginning to grapple with questions regarding where these materials fit into library collections, the Web changed everything. CDROM development seems to be waning because users want everything delivered on the Web. Despite the tremendous technological barriers to multimedia delivery via the Web, commercial and academic forces are working to bring networked digital multimedia into our homes and classrooms. Academic media librarians must be prepared to meet these challenges. We know the content and we know our users. We must use what we already know to help create the systems to bring multimedia resources to the students and faculty we serve.

\section{Developing the 1999 guidelines}

The 1999 "Guidelines for Media Resources in Academic Libraries" were developed by the 1995-1997 ACRL Media Resources Committee, with input from a variety of media and library professionals. The draft guidelines went through numerous revisions, based upon input from many librarians. The members of the Media Resources Committee sought input from other librarians at many points in the process within ALA and via mail lists. We also sought input from media specialists and administrators in higher education. The committee mounted the Web-based version, then distributed the URL to several mail lists and to related ACRL committees. The 1997-1998 Media Resources Committee revised and refined the document based on the resulting comments. This draft was published in the May 1998 issue of CERL Neus. The committee held a hearing at the Annual Conference in Washington, D.C. and

(continued on next page) 
(continued from pretious page)

committee revised the guidelines based upon comments received at the hearing. This draft was submitted to the ACRL Standards and Accreditation Committee, which also offered suggestions. The final guidelines represent the work of many individuals over several years. In addition to the members of the Media Resources Committee listed below, I would like to acknowledge the valuable assistance we received from Barton Lessin, who was our liaison to the Standards and Accreditation Committee and then Chair during the final stages of the approval process. I would also like to thank Michael Godow, our ACRL staff liaison.
Members of the Media Resources Committee, 1995-1997: Luella E. Allen, University of Delaware; Phillip Andt, South Arkansas Community College; Doris Bowers, Community College of Allegheny County; Kristine R. Brancolini, Indiana University (Chair, 1997-99); Foster Flint, Mississippi Gulf Coast Community College; Carleton Jackson, University of Maryland; Gary A. Lare, University of Cincinnati; Paula Murphy, Dominican University; Mary Konkel, University of Akron; Jill Ortner, State University of New York; Francis C. Poole, University of Delaware and Rick E. Provine, University of Virginia (Chair, 1995-97). -Kristine Brancolini, hrancoli@indiana.edu

\section{GUIDELINES}

Given the stated assumptions, the specific guidelines for media resource collections and services will assist academic libraries in strengthening their media resources programs. The ACRL Guide to Policies and Procedures states:

"Guidelines consist of procedures that will prove useful in meeting the standards. In order for a document to be classified as a guideline, it must:

1. Be specific to programs, service, or staffing.

2. Identify a framework for developing services policies and procedures."

\section{Objectives}

1.0 Librarians should develop a mission statement for the media resources program based upon the mission statement of the library.

Commfntary: A clear, unambiguous statement of the role of the media resources program is essential for planning and evaluation regardless of the organizational structure of the library. Whether or not there is a separate media department within the library, a mission statement is essential to an effective media program.

\section{Organization/administration}

2.0 The responsibilities and functions of the media resources program should be clearly defined within the organizational structure of the library. The administration of the library should assign responsibility for the media resources program to a librarian.

COMmintary: In order to develop an effective media resources program, a librarian must be responsible for planning collections and services. Depending upon the organizational structure of the library, this librarian may manage a separate media resources unit or department, may work within another library unit, or coordinate the activities of librarians (for example, subject specialists) and other staff from several units.

\subsection{The librarian responsible for the me-} dia resources program should take a proactive role within the institution, beyond the library, working cooperatively and collaboratively with personnel in other media-related units on campus.

COMmFNTARY: Most colleges and universities have more than one unit delivering media services. The media resources librarian should actively promote the library's collections and services among these personnel and plan cooperative ventures with them as appropriate. These relationships might also include computing center personnel, particularly those involved with multimedia.

\section{Staff}

3.0 The librarian responsible for the media resources program should have a 
graduate degree from an ALA-accredited program in library or information science.

COMmentary: While we recognize that library staff with other media-related degrees may bring expertise to a library's media re sources program, the program will be strengthened if managed by a qualified librarian. This librarian should have coursework and/or experience in working with academic library media resources. This coursework may include film studies, mass communications or related fields, depending upon the scope of the librarian's responsibilities.

\subsection{The librarian responsible for the me-} dia resources program should be encouraged to belong to and participate in media-related professional associations and other professional development activities.

Commentary: It is likely that the media librarian will be the only professional within the library working predominantly with media resources. Because of the issues inherent to collecting and delivering media resources, other media librarians are often the only source of professional support and specialized information.

3.2 libraries should fund continuing education opportunities and conference attendance for the librarian responsible for the media program.

COMMENTARY: The changing nature of media resources programs and ongoing changes in technology mandate participation in continuing education that may exceed the expectations for all library staff. Most academic libraries have only one media librarian; thus, conferences afford important opportunities to share ideas with other media librarians and attend relevant meetings.

3.3 Support staff for the media resources program should have specialized media training and technical expertise.

ComminTaRY: The media librarian cannot provide all of the necessary support for an effective media resources program. The specific support staff needed and their expertise will vary according to the program at each library. However, the skills and responsibilities of the staff should be clefined clearly and be updated regularly.

\section{Budget}

4.0 The media resources mission statement should form the basis for the program budget and be part of the library planning process.

COMMENTARY: The media resources mission statement and annual objectives form the basis for the program budget. Stable and consistent funding for acquisitions based on an approved collection development policy is necessary for effective service.

4.1 An ample and stable budget for the acquisition of media resources should be based either on a percentage of the total library acquisitions budget or on a formula related to collection use as measured by circulation statistics.

COMmENTARY: Basing the media resources materials budget on a percentage of the acquisitions budget assures that large academic libraries allocate a reasonable amount of funding to building media resources collections. Using circulation statistics to determine funding levels for the purchase of media resources assures that a high-use collection will be able to meet the demand for new titles, additional copies of popular titles, and replacement of worn materials. Materials budgets should also be large and flexible enough to support the exploration of new media formats along with traditional formats.

4.2 Media equipment is essential to providing access to media resources. The library should establish an ample and stable budget for the maintenance and purchase of media equipment. The addition and replacement of equipment should be based upon a written plan.

COMMENTARY: Libraries cannot provide access to media resources without sufficient and well-maintained equipment. The level of funding should be based upon the life expectancy for equipment and in-house use of the collection. A budget plan for media equipment should include the repair and replacement of worn equipment, the need to provide upgrades to existing equipment, and the purchase of additional equipment as user demand increases. The plan should also anticipate the adoption of new technologies and the need to expand support for new kinds of equipment. Equipment maintenance and replacement have a major impact on the longevity of collections. 


\section{User services}

5.0 The media resources program should provide a variety of services that support and expand the media resources collection.

COMmentary: It is expected that libraries will provide circulation and other typical collection services for media collections. However, media resources require services particular to media collections, such as a centralized distribution system, group viewing facilities, media booking, off-satellite videotaping, teleconference downlinking, and so on.

5.1 Media resources should be accessible through resource sharing, in accordance with the ALA Video Round Table Guidelines for the Interlibrary Loan of Audiovisual Formats.

COMmEnTARY: Many libraries treat media collections as special collections and prohibit their interlibrary loan. However, library users benefit when media collections are included in resource-sharing programs. No library can meet all of its users' needs for media resources, but libraries are reluctant to lend to our users if we do not lend to their users. The guidelines recognize that some materials may be excluded, but in general, there is no reason to exclude entire formats from interlibrary lending.

5.2 Specialized media-related reference services, supported by appropriate print and electronic reference sources, should be available to assist the students, faculty, and staff in meeting their instructional, informational, and research needs.

COMMENTARY: Users may need assistance in identifying relevant media resources to use in instruction and research. Instructors may need assistance in developing instruction using media resources. General reference librarians often do not have the necessary training to provide these information services.

5.3 The necessary equipment to access media resources should be available and maintained to provide ready access to collections.

COMMENIARY: Media collections cannot be used without the necessary playback equipment. While some media collections circulate outside the library, many do not or portions of the collection do not. Some users do not own or have other access to playback equipment. It must be available in the library. 5.4 Instruction programs should incorporate the use of media resources as information sources for instruction and research.

COMMENTARY: Just as instruction programs have now incorporated information available on the Web, locating and using media resources should also be a part of library instruction. Library courses and instruction in information literacy should include visual literacy and media literacy.

5.5 The media resources librarian should offer assistance to educators who want to integrate the use of media resources into their courses, either as a part of classroom instruction or as supplemental study in the library.

COMmentaRY: The media resources librarian should actively promote use of the collection in teaching by offering services to faculty in locating local media resources for a new or revised course, suggesting ways in which these materials might be used, locating resources available at other libraries or for purchase, and generally assisting in the use of these materials. Media librarians should be included on collaborative teams developing new courses, as many faculty are unfamiliar with the tools needed to locate and evaluate media resources.

\section{Collections}

6.0 The media resources program should make available an organized collection of materials and information in diverse formats.

6.1 The library should have a separate, written collection development policy statement to serve as the basis for selection and acquisition of media resources.

COMMHNTARY: The library's overall collection development policy will include media resources, but a separate policy is needed to establish priorities and guide selections. Selection decisions are different from format to format. These differences must be described in the collection development and selection policies

6.2 The selection of media resources materials should be the shared responsibility of librarians specifically charged with building the media resources collection and the subject selectors. 
Commentary: The selection of media resources is different from the selection of print materials. Media selection requires the use of specialized review sources and may include previewing of materials under consideration or purchasing on approval. Media selectors need special training and skills. However, subject selectors provide necessary content expertise when considering more specialized media resources.

6.3 Obsolete, worn out materials should be systematically removed from the collection and replaced if necessary.

COMmFNTARY: Worn materials represent a hazard to equipment. Most academic libraries, including research libraries, do not maintain archival media collections on site, due to the need to maintain outdated equipment. These materials are usually housed in separate archival collections. See 7.2 below for amplification. Access collections require a vigorous program of weeding and replacement.

6.4 Libraries should develop procedures to address media resources on dying and obsolete formats, in order to preserve access to content that is jeopardized by changing technologies.

Commentary: As equipment becomes obsolete and unavailable, the media librarian should have a plan for preserving the content of the software. The procedures for decision making should consider whether the materials are in an archival collection or in an access collection and whether they should be replaced or reformatted. Permission to reformat may need to be secured from the copyright holder. However, the 1998 Digital Millennium Copyright Act permits the reformatting of materials from obsolete formats without permission. See the revisions to Section 108 for specific provisions (United States Code 17).

6.5 The media resources reference collection should include a wide selection of standard works and specialized reference tools in all formats.

Commentary: In addition to publications designed specifically to aid in the use of media resources, bibliographic utilities provicle information available in no other source. 13ibliographic utilities should be readily available to both the media librarian and library users, as important sources of information about media materials. Library Web sites should include links to the vast array of online resources available to librarians for collection building and reference. Most media reference work focuses on finding appropriate media resources on a specific topic and determining their availability. Print tools are inadequate to satisfy many of these queries.

\section{Facilities}

7.0 The media resources program should provide adequate space for housing collections and for use of the materials. Any renovation of media space should consider the rapidly evolving world of digital media and the attendant networking requirements. Magnetic materials and optical storage media require specialized storage for conservation and preservation. Archival collections should receive special treatment and handling.

COMmentary: Recommended storage and hanclling practices vary by type of material and by intended use. Access collections should be treated differently from archival collections. Libraries should have policies for all the variations in their particular collection.

7.1 Media resources should be available in a variety of playback situations, including a mixture of individual, small group, and large group viewing facilities.

COMminTARY: While most other information sources are designed to be used by individual users, many media resources are designed to be used in groups. Others are designed to be used by individuals. Libraries must accommodate all types of users in a variety of settings

7.2 Archival media resources collections require specialized storage and handling. The library should establish a program for archiving media resources, even if housed in a separate special collection.

Commintary: While most media resources collections are access collections, some may require more long-term environmental considerations.

\section{Bibliographic access and cataloging} 8.0 Bibliographic and holdings information about media resources should be made accessible through the same retrieval mechanisms available for other library materials. 
COMmentary: Library catalogs should represent the complete holdings of the library regardless of format. Media resources may be unique information sources-oral/visual histories, classroom observations, simulations, clinical diagnostic techniques. These materials could be overlooked without proper bibliographic access in library catalogs.

8.1 Media resources should be cataloged in accordance with current national standards and practices, including full subject access, description, system requirements, and classification to provide maximum information to the user of the library catalog.

COMmentary: Following national standards for cataloging media resources will uphold the quality of our library catalogs, enhance bibliographic retrieval, and provide necessary information to users about subject content and equipment requirements. Bibliographic access points should incorporate subjects, alternate titles, subtitles, translations of titles, series, and persons or bodies responsible for the performance or the primary content of the media resource. Full cataloging provides the user with optimal retrieval opportunities.

8.2 Media resources should be cataloged in a timely fashion, with a sufficient level of support for catalogers, equipment, and training to ensure that the materials will not be backlogged.

COMMENTARY: Media resources generally require more complex cataloging routines and lengthier bibliographic descriptions. They also have physical characteristics that require unique processing. Therefore, media resources take more time to catalog and process than most print resources. Trained professional catalogers with media expertise require access to appropriate cataloging and indexing tools, playback equipment in all formats represented in the collection, and the Web.

8.3 Summary statements in bibliographic records should supply users with important information about the content and purpose of media resources and not simply repeat publicity statements found on packaging.

Commentary: Summary statements should provide the user with descriptive information about the content of media resources and their intended use, if available. This assists the users in determining whether the resource is likely to meet their needs. When the content requires subject expertise, the summary should be written with the assistance of appropriate subject specialists.

\section{References}

ALA Video Round Table Guidelines for the Interlibrary Loan of Audiovisual Formats. January 1998. URL: http://www.lib.virginia. $\mathrm{edu} / \mathrm{dmm} / \mathrm{VRT} /$ illguide.html.

Guidelines for Audio-Visual Services in Academic Libraries. Prepared by the Audio-visual Committee of the ACRL. Chicago: ACRL, American Library Association, 1968 .

"Guidelines for Audiovisual Services in Academic Libraries." Prepared by the ACRL Audiovisual Committee, Margaret Ann Johnson, chair. CERL News 48 (October 1987): 533-536.

United States Code. Title 17-Copyrights. Legal Information Institute. URL: http:// www.law.cornell.edu/uscode/17/.

\section{Media bibliography}

Audiovisual Policies in ARL Libraries. SPEC Kit 162, March 1990. Washington, D.C.: Office of Management Studies, Association of Research Libraries. Documents compiled and SPEC flyer by Kristine Brancolini.

Audiovisual Policies in College Libraries. CLIP Note \#14. Compiled by Kristine Brancolini. Chicago: ACRL, American Library Association, 1991.

Brancolini, Kristine and Provine, Rick E. Video Collections and Multimedia in ARL Libraries: Changing Tecbnologies. OMS Occasional Paper $\# 19$. Washington, D.C.: Office of Management Services, Association of Research Libraries, April 1997

Guidelines for Bibliograpbic Description of Interactive Multimedia. Interactive Multimedia Guidelines Review Task Force. Laurel Jizba, Chair. Chicago: American Library Association, 1994.

Intner, Sheila and Studwell, William E. Subject Access to Films and Videos. Lake Crystal, Minn.: Soldier Creek Press, 1992.

Olson, Nancy B. 1996 Update to Cataloging Motion Pictures and Videorecordings. 
Lake Crystal, Minn.: Soldier Creek Press, 1996.

Olson, Nancy B. Cataloging of Audiovisual Materials. Fourth edition, revised Dekalb, Ill.: Media Marketing Group, 1997.

Van Bogart, John W. C. Magnetic Tape Storage and Handling: A Guide for Libraries and Archives. Washington, D.C.: The Commission on Preservation and Access, 1995.

Video and Multimedia Collections in ARL Libraries. SPEC Kit 199, December 1993. Washington, D.C.: Office of Management Studies, Association of Research Libraries. Documents compiled and SPEC flyer by Kristine Brancolini and Rick E. Provine.

Video Collection Development in Multitype Libraries: A Handbook, edited by Gary Handman, Westport, Conn: Greenwood Press, 1994.

\section{ACRL guidelines and standards consulted}

These guidelines and standards are also available on the ACRL Web site. URL: http:// www .ala.org/acrl/guides/index.html.
"Guidelines for Extended Academic Library Services: A Draft," CERL News 58 (February 1997): 98-102.

"Guidelines for Instruction Programs in Academic Libraries," CERL Neus 58 (April 1997): 264-266.

"Guidelines for University Undergraduate Libraries," CERL News 58 (May 1997): 330-333+.

"Standards for College Libraries," CERL News 56 (April 1995): 245-257.

"Standards for Community, Junior, and Technical College Learning Resources Programs," CERL News 55 (October 1994): 572585.

"Standards for Faculty Status for College and University Librarians," CERL News 53 (May 1992): 317-318.

\section{Note}

1. Archival collections contain unique or rare materials and should be preserved as long as possible. Access collections containing materials needed for immediate use and for magnetic media usually have a functional lifetime of approximately ten years.

\section{$\int \sqrt{(1), 1} \mid$

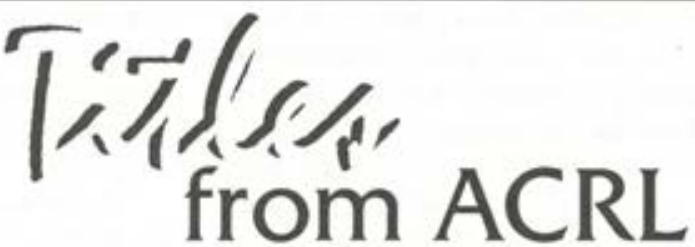

The Reference Encounter: Interpersonal Communication in the Academic Library, Publications in Librarianship no. 52 Marie L. Radford

This book challenges the traditional view of reference goals: the belief that users seek only satisfactory answers to their questions. It adds to our current understanding of this complex process by exploring interpersonal issues in the academic reference encounter through indepth interviews following reference interactions at academic libraries.

List price: $\$ 30.00$; member price: $\$ 27.00$; ISBN 0.8389-7951-3

\section{Friends of College Libraries, $2^{\text {sd }}$ Edition: CLIP Note $\$ 27$}

Ronelle K. H. Thompson and Ann M. Smith, compilers

This volume explores issues involved in establishing library friends groups. It includes a survey of library practices as well as sample documents such as constitution and bylaws, membership brochures, program ideas, newsletters, publications, and more. List price: \$28.00; member price \$25.00; ISBN 0-8389-8002-3

To Order Write: ALA Order Fulfillment, 155 N. Wacker Drive, Chicago, IL 60606 Call: $800-545-2433$, (press 7)

Fax: $312-836-9958$ 


\section{Jounal of Visual \&mparment Binchess}

\section{$J V I B$, the international, interdisciplinary journal of record on blindness and visual impairment.}

The Journal of Visual Impairment \& Blindness is a comprehensive journal that combines timely news material and academic research in one source. JVIB has been used as a platform to exchange ideas, air controversies, and discuss the current issues in the field for more than 90 years.
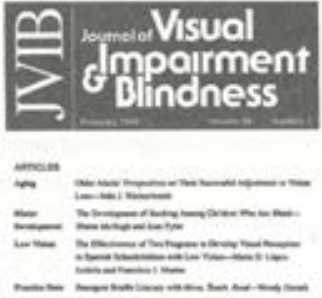

rot nemenve:

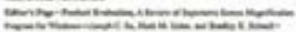
trolven.

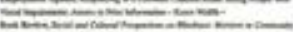

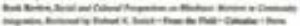

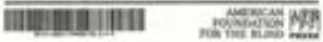

- All articles are peer reviewed

- Issues of JVIB are kept and referred to again and again

- Focuses on national and international concerns

\begin{tabular}{|ccr|}
\hline \multicolumn{3}{|c|}{ SUBSCRIPTION RATES } \\
INDIVIDUAL & one year & $\$ 90.00$ \\
INSTITUTIONAL & one year & $\$ 125.00$ \\
\hline
\end{tabular}

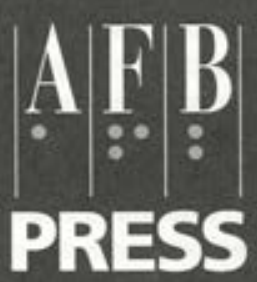

Journal of Visual Impairment \& Blindness

Subscription Services

The Sheridan Press

P.0. Box 465

Hanover, PA 17331

Tel 1-888-522-0220

www.afb.org 